\title{
Pay as You Go: Prepaid Metering and Electricity Expenditures in South Africat
}

\author{
By B. Kelsey JaCK and GRant Smith*
}

Much of the coming growth in energy demand is expected to come from the developing world (Wolfram, Shelef, and Gertler 2012). Existing evidence on the effects of electrification suggests that this is good news for development (Dinkelman 2011; Lipscomb, Mobarak, and Barham 2013). However, it also introduces new challenges for both households and electric utilities since newly electrified households are likely to be poorer and more liquidity constrained. Thus, they may struggle to pay lumpy utility bills, resorting to non-payment when they do not have enough cash on hand or when service quality is poor (Szabó and Ujhelyi 2014; McRae 2015). Utilities must provide larger amounts of energy at higher marginal costs and balance concerns over non-payment with the political and logistical cost of disconnecting households.

We study a technological solution to the non-payment problem among low-income households: prepaid electricity meters. Prepaid meters constitute a large share of residential electricity connections in South Africa and are undergoing a rapid expansion in the developing world. We use detailed customer transaction data from Cape Town, South Africa to characterize electricity expenditures under prepaid metering. By studying how expenditure patterns vary with property values, we provide suggestive

\footnotetext{
* Jack: Tufts University, 314 Braker Hall, Medford, MA 02155 (e-mail: Kelsey.Jack@tufts.edu); Smith: University of Cape Town, Level 3, School of Economics Building, Middle Campus, Rondebosch, Cape Town, 7700, South Africa (e-mail: g.smith@uct.ac.za).We thank the City of Cape Town for collaboration on the research, Rema Hanna, Koichiro Ito, Gilbert Metcalf, Ben Olken, and Lucy Qiu for comments on the paper, Kathryn McDermott and Grant Bridgman for excellent research assistance, and the ICTS High Performance Computing Cluster at UCT for access to its server. The Urban Services Initiative at J-PAL and the International Growth Centre provided financial support.

${ }^{\dagger}$ Go to http://dx.doi.org/10.1257/aer.p20151096 to visit the article page for additional materials and author disclosure statement $(\mathrm{s})$.
}

evidence that expenditures by poorer households are driven by liquidity constraints and a difficulty smoothing income. This indicates that the monthly billing model is inconsistent with a revealed preference for small infrequent purchases among the poor, a preference also documented in other settings (e.g., Attanasio and Frayne 2006).

\section{Residential Electricity in Sub-Saharan Africa}

Over the past two decades, the share of households in Sub-Saharan Africa with access to electricity has crept up slowly, from 16 percent in 1990 to just over 30 percent in 2011. In contrast, during that same time period, South Africa went from a connection rate comparable to elsewhere in Sub-Saharan Africa to over 80 percent access (National Energy Regulator of South Africa 2002; International Energy Agency 2013).

South Africa's rapid electrification program relied on a technological solution to ensuring timely electricity payments: prepaid meters (Bekker et al. 2008). This payment innovation mirrors the predominant billing system for cellular technologies in developing countries, which have expanded rapidly among the very poor. Like a prepaid mobile phone, users load credit onto the meter using a meter-specific encrypted code purchased from a physical vendor or online or mobile retailer. The credit is then drawn down until the balance reaches zero and the power shuts off until more credit is loaded. 1

Prepaid electricity meters appear poised to spread rapidly in the developing world. At present, there are more prepaid meters in South Africa than in the rest of Sub-Saharan Africa combined, though a recent industry report

\footnotetext{
${ }^{1}$ Electricity theft, which requires physical tampering with the meter or wiring, becomes the only feasible form of non-payment.
} 
TABLE 1-Summary Statistics

\begin{tabular}{lccrrr}
\hline \hline & Mean & Median & SD & Min. & Max. \\
\hline Months in panel & 71.666 & 74 & 44.465 & 1 & 131 \\
Average transactions per month & 8.453 & 5.844 & 8.267 & 1.000 & 195.831 \\
Average ZAR per month & 638.282 & 474.541 & 650.285 & 0 & $21,000.000$ \\
Average kWh per month & 587.925 & 481.517 & 474.296 & 5.300 & $18,000.000$ \\
ZAR per transaction & 65.862 & 29.334 & 112.978 & 0 & $3,954.325$ \\
kWh per transaction & 78.367 & 39.769 & 118.430 & 5.300 & $2,943.430$ \\
Property value ('O00 ZAR) & 910 & 570 & 1,200 & 3.827 & 9,700 \\
\hline
\end{tabular}

Note: Summary statistics at the customer $(N=31,570)$ and transaction $(N=15,667,457)$ level.

forecasts the number of prepaid meters in Sub-Saharan Africa to grow by 200 percent in the coming decade (Northeast Group 2014).

\section{Case Study: Cape Town, South Africa}

We examine the relationship between property value-which is likely correlated with socioeconomic status-and electricity purchasing patterns for residential prepaid electricity customers in Cape Town, South Africa between 2004 and 2014. Electricity is billed on an increasing block tariff, which resets on the first of each month. Customers move up the tariff schedule based on cumulative purchases during the month.

\section{A. Data}

We assemble a customer-level panel dataset using administrative records from the City of Cape Town's municipal electric utility. [2 Approximately 665,000 residential customers were served by the utility in 2014,78 percent of whom were on prepaid metering. Our unit of observation is a prepaid electricity transaction; we observe the size (in South African Rand (ZAR) and $\mathrm{kWh}$ ), date, and time of each purchase. We do not observe electricity consumption outcomes. We combine the transaction data with property value records from 2012.

\footnotetext{
${ }^{2}$ The data and dataset construction are described in greater detail in an online Appendix, together with additional summary statistics and robustness checks.

${ }^{3}$ This represents the most recent available property value for most dwellings in the City of Cape Town's administrative records.
}

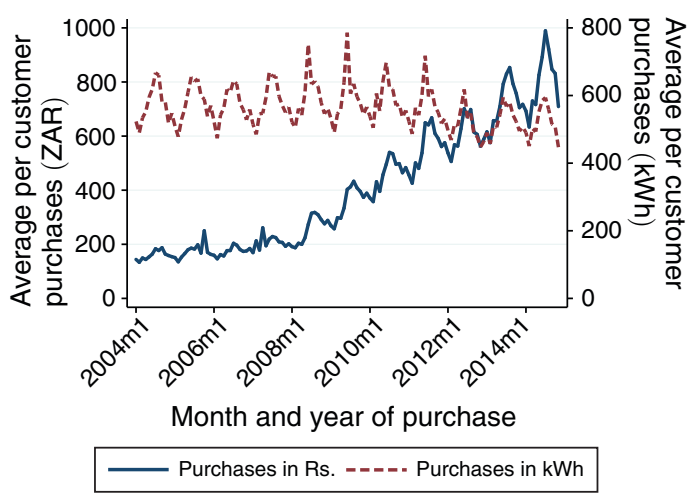

Figure 1. Monthly Purchases

Note: Average per-customer monthly purchases in ZAR and kWh.

\section{B. Descriptive Statistics}

We analyze a 10 percent sample of the prepaid residential customers for whom we have valid property values: 31,570 customers and $15,667,457$ observations. Table 1 shows sample statistics. All monetary units are in 2012 South African Rand (ZAR (2012) $1=$ USD (2012) 8.54). The median customer is observed in the dataset for 74 months and purchases an average of $481.5 \mathrm{kWh}$ of electricity per month in 5.8 separate transactions. For comparison, the Energy Information Administration reports that the average US household consumed $903 \mathrm{kWh}$ of electricity per month in 2012.

Purchasing patterns vary considerably over time. As shown in Figure 1, monthly expenditures have increased since 2004, while purchase quantities in kWh have remained relatively constant. This pattern is explained by annual tariff increases, particularly since $2007 / 2008$. 
TAble 2-Expenditure Patterns

\begin{tabular}{|c|c|c|c|c|c|}
\hline & $\begin{array}{l}\text { Transactions } \\
\text { per month }\end{array}$ & $\begin{array}{l}\text { kWh per } \\
\text { month }\end{array}$ & $\begin{array}{l}\text { ZAR per } \\
\text { month }\end{array}$ & $\begin{array}{l}\text { ZAR per } \\
\text { transaction }\end{array}$ & $\begin{array}{c}\text { Property value } \\
\text { elasticity }\end{array}$ \\
\hline Quartile 1 & & & & & $\begin{array}{l}0.221 * * * \\
(0.005)\end{array}$ \\
\hline Quartile 2 & $\begin{array}{c}-1.336^{* * * *} \\
(0.133)\end{array}$ & $\begin{array}{c}122.665^{* * * *} \\
(3.697)\end{array}$ & $\begin{array}{c}104.684 * * * \\
(3.473)\end{array}$ & $\begin{array}{l}8.827 * * * \\
(0.497)\end{array}$ & $\begin{array}{l}0.356^{* * * *} \\
(0.006)\end{array}$ \\
\hline Quartile 3 & $\begin{array}{c}-5.427 * * * \\
(0.112)\end{array}$ & $\begin{array}{c}246.139 * * * \\
(4.586)\end{array}$ & $\begin{array}{c}225.693 * * * \\
(4.281)\end{array}$ & $\begin{array}{l}46.541 * * * \\
(1.650)\end{array}$ & $\begin{array}{l}0.478 * * * \\
(0.006)\end{array}$ \\
\hline Quartile 4 & $\begin{array}{l}-7.064 * * * \\
(0.104)\end{array}$ & $\begin{array}{l}521.983 * * * \\
(7.870)\end{array}$ & $\begin{array}{c}465.666^{* * * *} \\
(6.749)\end{array}$ & $\begin{array}{c}128.658 * * * \\
(8.319)\end{array}$ & $\begin{array}{l}0.530 * * * \\
(0.005)\end{array}$ \\
\hline Observations & $2,262,647$ & $2,262,647$ & $2,262,647$ & $15,667,457$ & $2,262,647$ \\
\hline Quartile 1 mean & 10.208 & 340.258 & 249.384 & 24.431 & \\
\hline
\end{tabular}

Notes: All regressions include month and year fixed effects and cluster standard errors at the customer level $(N=31,570)$. Columns 1,2,3, and 5 are estimated on a monthly panel; column 4 is estimated on a transaction-level panel. Column 5 reports the point elasticity of kWh per month with respect to property value, calculated at the median property value in each quartile. See the online Appendix for further detail.

*** Significant at the 1 percent level.

**Significant at the 5 percent level.

* Significant at the 10 percent level.

\section{Heterogeneity by Property Value}

We expect liquidity constraints to present a greater barrier to income smoothing among poorer households. To isolate the relationship between property values and purchasing patterns, we estimate

$$
y_{i t}=\sum_{q=2}^{4} \delta_{q} \operatorname{prop}_{q}+\gamma_{m}+\eta_{y}+\epsilon_{i t}
$$

where $y_{i t}$ is an outcome for customer $i$ at time $t$. Each $\delta_{q}$ captures the effect of a property value quartile relative to the first quartile. We include month $(\gamma)$ and year $(\eta)$ fixed effects to control for seasonality and annual trends. We weight each customer by the number of times the customer appears in the panel and cluster standard errors at the customer level.

Table 2 presents the relationship between property values and purchasing patterns. The number of transactions per month is decreasing across property value quartiles, with an average of around ten transactions per month in the bottom quartile and around three in the top quartile (column 1). The average monthly expenditure in both ZAR and $\mathrm{kWh}$ is increasing across property value quartiles (columns 2 and 3 ). Column 4 shows that the average transaction goes from around ZAR (2012) 24 (just under
US\$3) in the lowest property value quartile to around ZAR 153 in the highest quartile. Finally, column 5 presents the estimated point elasticities of monthly $\mathrm{kWh}$ purchases with respect to property value, calculated at the median property value within each quartile. ${ }^{4}$ The elasticity is increasing across quartiles, and is in line with estimates of the income elasticity of electricity demand from other developing country settings (Khanna and Rao 2009)! 5

These descriptive patterns indicate that households in the bottom quartile purchase over three times as often (every three days) and in increments that are less than a fifth as large as those in the top quartile. Small, frequent transactions are consistent with liquidity constraints and difficulty smoothing income.

We turn next to a more direct examination of income smoothing. Liquidity constrained households may be more likely to spend money

\footnotetext{
${ }^{4}$ We include a squared term for property values in the estimating equation to allow for a non-linear relationship between kWh purchases and property value. Because property value is time invariant in our data, results should be interpreted as long run elasticities.

${ }^{5}$ Income elasticities of electricity demand are expected to be higher in developing than in developed countries (Wolfram, Shelef, and Gertler 2012). Residential long run income elasticities in the developing country studies reported in (Khanna and Rao 2009) range from 0.2 to 1.8 .
} 
when income arrives, which occurs on Fridays for many wage laborers. We analyze the share of a customer's transactions that occur on each day of the week, and we modify equation (1) to interact quartiles with day of the week indicators. We show the estimated marginal effects in the top panel of Figure 2. Higher purchase shares on Fridays are evident in the lower half of the property value distribution and, in particular, in the bottom quartile. Moving up the property value distribution, the pattern of Eriday purchases disappears almost completely. The F-statistic for the test that purchase shares are equal across days in the second half of the week (Wednesday-Saturday) is 488.05 for quartile 1 and 4.39 for quartile 4 .

More frequent purchases on Fridays may be due both to liquidity constraints and to the fact that poorer households are more likely to receive weekly wages. We repeat the analysis using purchase shares by day of the month in the bottom panel of Figure 2. Purchase shares are more evenly distributed in the top property value quartile. We see little evidence of purchase increases on salary paydays (fifteenth, twenty-fifth, or thirtieth) in the top quartile, though the middle two quartiles display significant increases in purchase shares on the fifteenth and twenty-fifth of the month. The bottom quartiles display relatively large spikes in purchase shares on the first of the month, when the tariff resets and the same amount of money purchases more kWh of electricity 7

The observed distribution of purchases over time varies considerably between richer and poorer households. Customers with low property values purchase more often immediately following a common payday, and are more sensitive to the tariff structure in their allocation of purchases across the month.

\footnotetext{
${ }^{6}$ We speculate that the higher purchase shares on Mondays in the top property value quartile may be attributed to the start of the work week.

${ }^{7}$ Note that because the tariff increases over the course of the month are based on cumulative expenditures by the customer, total spending is unaffected by when during the month a purchase takes place. Thus, delaying expenditures until the first of the month is consistent with difficulty smoothing income.
}

Panel A

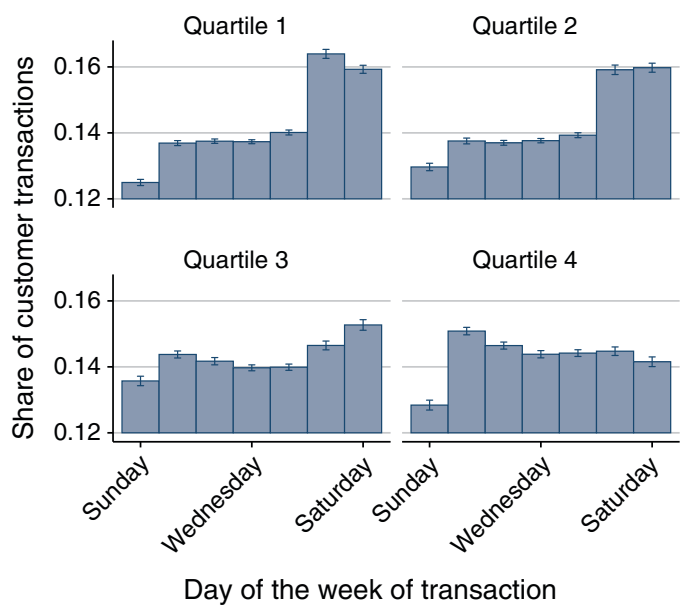

Panel B

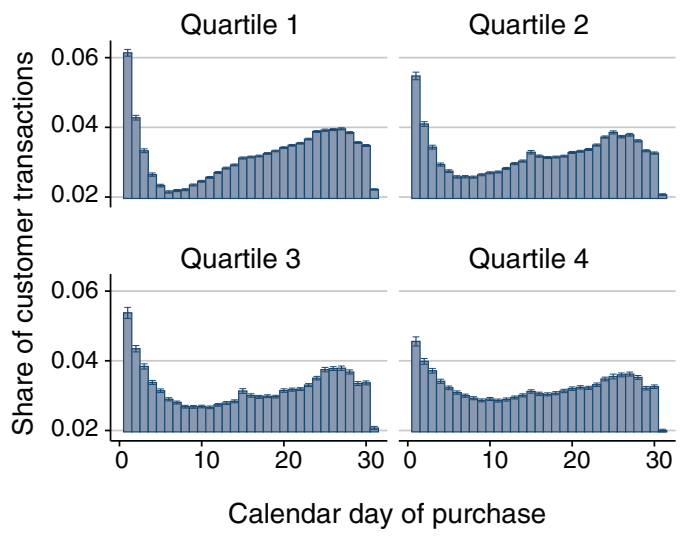

Figure 2. Heterogeneity by Property Value Quartile

Note: Estimated marginal effects for the share of customer purchases on each day of the week (panel A) and day of the month (panel B).

\section{Conclusion}

In addition to addressing non-payment of utility bills, prepaid electricity meters introduce new flexibility in how and when poor, liquidity constrained households purchase electricity. To the extent that difficulty smoothing income underlies the failure to pay monthly bills, this added flexibility allows customers to smooth expenditures to income and potentially improves customer welfare. We observe that poor households in Cape Town take advantage of the added flexibility by purchasing electricity often and in 
small amounts. A relatively sparse literature has documented similar patterns of small, frequent purchases of a variety of consumption goods by poor households in developing countries (Attanasio and Frayne 2006).

The question remains as to why poor households find monthly payments difficult. The sensitivity to payday and to the tariff schedule shown in our analyses is consistent both with expenditures driven by liquidity constraints (e.g., Johnson, Parker, and Souleles 2006) and with more behavioral explanations, such as time inconsistency (e.g., Shapiro 2005) $\left[{ }^{8}\right.$ Better understanding of the reasons poor households fail to pay their electricity bills, and the potential set of tools-including but not limited to prepaid metering - to increase payment rates, is crucial for expanding energy access to the poor in the developing world.

\section{REFERENCES}

Attanasio, Orazio P., and Christine Frayne. 2006. "Do the Poor Pay More?" http://www. homepages.ucl.ac.uk/ uctpjrt/Files/poor.pdf (accessed December 15, 2014).

- Bekker, Bernard, Anton Eberhard, Trevor Gaunt, and Andrew Marquard. 2008. "South Africa's rapid electrification programme: Policy, institutional, planning, financing and technical innovations." Energy Policy 36 (8): 3125-37.

Dinkelman, Taryn. 2011. "The Effects of Rural Electrification on Employment: New Evidence from South Africa." American Economic Review 101 (7): 3078-3108.

International Energy Agency (IEA). 2013. "World Energy Outlook Electricity Access Database." International Energy Agency. http:// www.worldenergyoutlook.org/resources/ energydevelopment/energyaccessdatabase/ (accessed December 15, 2014).

- Johnson, David S., Jonathan A. Parker, and Nicholas S. Souleles. 2006. "Household Expenditure and the Income Tax Rebates of 2001." American Economic Review 96 (5): 1589-1610.

-Khanna, Madhu, and Narasimha D. Rao. 2009. "Supply and Demand of Electricity in the Developing World." Annual Review of Resource Economics 1 (1): 567-96.

-Lipscomb, Molly, A. Mushfiq Mobarak, and Tania Barham. 2013. "Development Effects of Electrification: Evidence from the Topographic Placement of Hydropower Plants in Brazil." American Economic Journal: Applied Economics 5 (2): 200-31.

-McRae, Shaun. 2015. "Infrastructure Quality and the Subsidy Trap." American Economic Review 105 (1): 35-66.

National Energy Regulator of South Africa (NERSA). 2002. Electricity Supply Statistics for South Africa 2002. Pretoria, South Africa: National Electricity Regulator.

Northeast Group. 2014. Sub-Saharan Africa Electricity Metering: Market Forecast (20142024). Northeast Group, LLC.

-Shapiro, Jesse M. 2005. "Is there a daily discount rate? Evidence from the food stamp nutrition cycle." Journal of Public Economics 89 (2-3): 303-25.

Szabó, Andrea, and Gergely Ujhelyi. 2014. "Can Information Reduce Nonpayment for Public Utilities? Experimental Evidence from South Africa." http://www.uh.edu/econpapers/ RePEc/hou/wpaper/2014-114-31.pdf (accessed April 28, 2014).

-Wolfram, Catherine, Orie Shelef, and Paul Gertler. 2012. "How Will Energy Demand Develop in the Developing World?" Journal of Economic Perspectives 26 (1): 119-38.

\footnotetext{
${ }^{8}$ The patterns we observe could also be driven by differences in transaction costs between richer and poorer households. Electricity can be purchased from a variety of vendors convenient for rich households, including grocery stores, gas stations, and via mobile phone or Internet.
} 


\section{This article has been cited by:}

1. Stephie Fried, David Lagakos. 2021. Rural Electrification, Migration and Structural Transformation: Evidence from Ethiopia. Regional Science and Urban Economics 99, 103625. [Crossref]

2. Mateo Cardona, Juan Miguel Gallego, John Jairo García, Jamer Arturo Franco. 2020. Prepaid electricity and in-home displays: An alternative for the most vulnerable households in Colombia. The Electricity Journal 33:8, 106824. [Crossref]

3. Usama Qazi, Shahid Iqbal, Hina Zaheer, Rehman Tauseef Ur. 2020. Prepaid metering: A way forward for sustainable power sector in Pakistan. Energy Strategy Reviews 31, 100546. [Crossref]

4. Mamadou Saliou Barry, Anna Creti. 2020. Pay-as-you-go contracts for electricity access: Bridging the "last mile" gap? A case study in Benin. Energy Economics 90, 104843. [Crossref]

5. Ognen Stojanovski, Gordon W. Leslie, Frank A. Wolak, Juan Enrique Huerta Wong, Mark C. Thurber. 2020. Increasing the energy cognizance of electricity consumers in Mexico: Results from a field experiment. Journal of Environmental Economics and Management 102, 102323. [Crossref]

6. Kelsey Jack, Grant Smith. 2020. Charging Ahead: Prepaid Metering, Electricity Use, and Utility Revenue. American Economic Journal: Applied Economics 12:2, 134-168. [Abstract] [View PDF article] [PDF with links]

7. Yuxiang Ye, Steven F. Koch, Jiangfeng Zhang. 2018. Determinants of household electricity consumption in South Africa. Energy Economics 75, 120-133. [Crossref]

8. Emma Li, Li Liao, Zhengwei Wang, Hongyu Xiang. 2018. Individual Consumption Response to Expanding Credit Access: Evidence from Online Cash Loan Platform. SSRN Electronic Journal . [Crossref]

9. Ognen Stojanovski, Gordon Leslie, Frank A. Wolak, Juan Enrique Huerta Wong, Mark C. Thurber. 2018. Promoting Energy Efficiency in Emerging Economies Through Consumer Education: Results From a Field Experiment in Mexico. SSRN Electronic Journal . [Crossref]

10. Mette Kragh-Furbo, Gordon Walker. 2018. Electricity as (Big) Data: Metering, spatiotemporal granularity and value. Big Data \& Society 5:1, 205395171875725. [Crossref]

11. William Parienté. 2017. URBANIZATION IN SUB-SAHARAN AFRICA AND THE CHALLENGE OF ACCESS TO BASIC SERVICES. Journal of Demographic Economics 83:1, 31-39. [Crossref]

12. Yueming Qiu, Bo Xing, Yi David Wang. 2017. PREPAID ELECTRICITY PLAN AND ELECTRICITY CONSUMPTION BEHAVIOR. Contemporary Economic Policy 35:1, 125-142. [Crossref]

13. Brian Dillon, Joachim De Weerdt, Ted O'Donoghue. 2017. Paying More for Less: Why Don't Households in Tanzania Take Advantage of Bulk Discounts?. SSRN Electronic Journal . [Crossref]

14. Brian Dillon, Joachim De Weerdt, Ted O'Donoghue. 2016. Paying More for Less: Why Don't Households in Tanzania Take Advantage of Bulk Discounts?. SSRN Electronic Journal . [Crossref] 